\title{
Impoverishing and dehumanising violence against women: An opportunity for service by churches in Eastern Democratic Republic of Congo
}

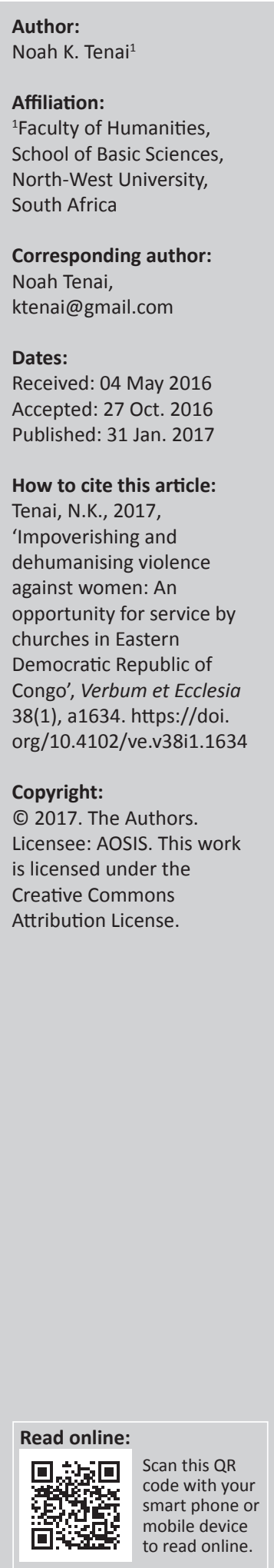

\begin{abstract}
An ongoing armed conflict in Eastern Democratic Republic of Congo continues to impoverish and dehumanise women. Sexual violence meted on women has negative consequences that affect whole communities. Churches nationally and in the region have not done enough to respond to the challenge of armed conflict in general and the nefariousness of sexual violence towards women in particular. By utilising the sustainable livelihoods framework, churches in the region can be re-positioned for a constructive advocacy response to armed conflict(s) and sexual violence(s), particularly in solidarity with the women.

Intradisciplinary and/or interdisciplinary implications: This study is made feasible through extensive intradisciplinary and interdisciplinary research. The subject matter demands on the investigator the necessity to make use of the knowledge from across the socio-scientific spectrum to understand the ongoing conflict and its impact on the local people. The study entrenches an advocacy role on regional churches as a means to lend a voice to the vulnerable women, who are impoverished and dehumanised by and within the context of an armed conflict.
\end{abstract}

\section{Introduction}

The article explores the status and effects of violence against women within a context of an ongoing armed conflict in Eastern Democratic Republic of Congo (DRC). The exploration is done with a view to establishing what roles churches could meaningfully play within the region. Violence has to end, and the humanity of the Congolese women has to be re-affirmed. As such, churches in the region have to find ways of responding to the ongoing impoverishment and dehumanisation resulting from an abiding armed conflict.

To what extend has the ongoing armed conflict in the Eastern DRC impoverished the Congolese women, and how can churches within the region respond? This article hinges on the preposition that violence against women in Eastern DRC has impoverished women's livelihoods, and that churches nationally and in the region, in particular, have not done enough to respond to the challenges resulting from and into violence meted on women. In contexts of armed conflict, such as the one that prevails in Eastern DRC, churches locally and nationally have a prophetic duty, even if that duty is but to be a voice to the voiceless.

The focus of this article is not on the general violence meted on women. Attention is given to violence of a sexual nature. Therefore, the focus is on the extent of sexual violence. The investigation is linked to possible advocacy role(s) of churches on behalf of women in instances of sexual violence, through a sustainable livelihoods framework.

It has been indicated (Leatherman 2011:32; Spangaro et al. 2015:1; Watts \& Zimmerman 2002:1232; Wood 2006:124-126) that sexual violence is a broad notion, which includes rape, coerced undressing, non-penetrative sexual assault and sexual mutilation. Sexual violence represents acts committed against a person, or a person is caused to engage by force, threat or coercion, such as fear of violence, duress, detention, oppression, or taking advantage of a coercive environment or a person's incapacity to give genuine consent. It is any act of gender-based violence, which results or may result in physical, sexual or psychological harm and suffering on the part of a female or even a male. Sexual violence is more than a physical act, as it has physical and psychological effects. In situations of conflicts, sexual violence vary in extent and forms. The violence may take the form of sexual slavery, which may entail abduction for sexual service(s) among combatants. It may also take the form of torture in detention, particularly in situations where some (women) 
belong to particular targeted groups. The aforementioned features of sexual violence abound in Eastern DRC.

There are broad collections of consequences of sexual violence against women (Arbuckle 2004:xii; Bufacchi 2007:18, 112; Dossa et al. 2014:5-10; Kirk-Duggan 2006:12; Leatherman 2011:9-30), particularly in situations of conflict, varying from forced pregnancy to displacement and elimination of targeted groups. Sexual violence is a strategy used to terrorise, control, displace and even eliminate. In armed conflicts, sexual violence against women may take various forms across time and cultures. Sexual violence is often accompanied by torture, brutality, slavery, mutilation and cannibalism.

In Eastern DRC, rape has become so common, to a point that even the United Nations' peacekeepers have been accused of rape and other forms of sexual violence against women (Moore 2016:1 of 1). Sexual 'violence', or the use of force to get sex, causes injury, damage, violation and destruction. Stated differently, sexual violence injures, damages, violates and destroys women. Violence destroys people and their possessions. Violence of any kind and sexual violence, in particular, dehumanises and destroys human creativity and the inner essence, by disallowing freedom. Sexual violence is an abuse, which lowers the victim's self-esteem and self-confidence. Sexual violence is subjugation resulting from and/or into powerlessness.

\section{Sexual violence against women in Eastern Democratic Republic of Congo: A contextual background}

Sexual violence against women occurs in Eastern DRC within a context of an ongoing conflict in Uvira, Goma and Bukavu (Melhado 2010:210; Nest, Grignon \& Kisangani 2006:31; Reyntjens 2009:10-77, 194-285; Turner 2013:15-16). There seems to be a link made between the Eastern DRC conflict and the historic 'Hutu-Tutsi' genocide that occurred in Rwanda and Burundi. It is argued that quite a number of both Hutus and Tutsis fled to the Eastern DRC. The DRC leaders, Laurent Kabila and his son - the current president, are alleged to have come to power with the assistance of Rwanda and Uganda. The Kabila's desire to govern the DRC independent of both Rwanda and Uganda has arguably left bitterness on the part of Uganda and Rwanda, who have resorted to arming various Hutu and Tutsi militia in the DRC to reign in on the Kabila administration. There is also a desire for control of DRC's mineral wealth. Eastern DRC has vast mineral resources. It is claimed that Uganda and Rwanda are likely profiting tremendously from their participation in the conflict and are able to extract and transport diamond and other minerals out of Eastern DRC, while their sponsored conflict is ongoing. Women, among others, find themselves as collateral in the ongoing conflict between the Uganda- and Rwanda-sponsored militia on the one side and the DRC soldiers on the other. It must be noted, however, that Uganda and Rwanda are not entirely to blame for the conflict in the DRC. Instability had characterised various regions of the DRC as far back as 1966.
From 1966 to 2001 alone, it is reported that $75 \%$ of women and $65 \%$ of men had been sexually violated. Those who had been sexually violated could link their violations to ongoing conflicts at the time. Women have had to deal with the realities of involuntary prostitution, unwanted pregnancies, mutilations, inhumane acts such as shooting and introduction of objects into their genitals. Despite efforts to integrate various groups (militia) into the military, Eastern DRC continues to be a scene of mass rape meted on women. In fact, Eastern DRC has been named the rape capital of the world, with about 15000 women raped in 2009 alone.

In Eastern DRC, insecurity and extreme brutal violence seem to directly coincide with sexual violence against women. Ongoing sexual violence in the form of rape is of a scale never witnessed before. Exposures to extreme sexual violence including horrific mutilations, which go beyond mere rape, are meted upon women, causing terror and displacements. Warring groups use sexual violence to demoralise and to deliberately incur severe sexual trauma on women associated with opponents. Between November 2008 and March 2009 alone, there were an estimated 1100 rapes which were reported in various health facilities in Eastern DRC (Mukwege \& Nangini 2009:1).

There is no doubt that the ongoing conflict in Eastern DRC has devastated women's livelihoods. The resultant poverty from the conflict and sexual violence meted upon them has driven a number of women into involuntary prostitution as a means of survival, which also in turn exposes them to further sexual violence. These survival sex relations have increasingly become commonplace, and abusive sexual relations among combatants and civilians are regarded as a service, easily obtained through coercive means. Although non-profit organisation (NGOs) and United Nations (UN) agencies continue to document incidences of rape and other forms of sexual violence against women in Eastern DRC, and despite the legal frameworks that recognise rape as a crime against humanity and as a war crime, sexual violence remains under the radar of the international community's eyes and there has been little success in curbing the use of rape (in particular and sexual violence in general), and other crimes against humanity in Eastern DRC (Melhado 2010:210).

There is no available information that indicates that rape has been an indigenous weapon in Eastern DRC. However, there is an apparent link between the ongoing rape culture and the armed conflict in the region, for the aforementioned reasons.

Women in the DRC, as in many other African nations, occupy critical roles requisite for the survival of families and communities. Those key socio-economic roles are mainly and not entirely a social construct. Women are mainly the caregivers, nurturers and workers for their communities. They are also the carriers of culture. As such, violence towards women, particularly that violence of a sexual nature, becomes attacks that strike at the very core of communities. Even though sexual violence in conflict contexts is pervasive, the practice has been recognised since 1990 as a crime against humanity. 
As such, there can be no excuse for the practice, although there have been arguments and myths to the effect that male soldiers who have unfulfilled sexual urges and irrepressible sexual drives resort to sexual violence during contexts of conflicts because of abnormalities caused by the disruption of normal morals and community rules resulting from conflict (Dossa et al. 2014:5-10; Kelly 2000:50; Meger 2010:120). In the region, women are notably subordinate to men in leadership, marriage, domestic responsibilities and safety from violence. Women are viewed as having little value beyond reproduction. They can achieve little to no value without marrying and reproducing. In marital relationship, women are far inferior to their husbands. Women who remain unmarried are regarded as prostitutes, regardless of whether or not she has a respectable profession with which to support herself (Fowler 2011:8-10).

The repercussions and reverberations of sexual violence against women continue to gain international attention and are acknowledged as traumatic and having negative impact, which result in the impoverishment and dehumanisation of women (Zihindula \& Maharaj 2015:736-737, 742), with physical, social and psychological consequences.

It is acknowledged (Duroch et al. 2011:1; Freedman 2011:170; Josse 2010:177; Le Roux 2014:40; Zihindula \& Maharaj 2015:738-741) that the physical consequences of sexual violence on women impact their health in various ways. Sexual violence on women carries with it risks and consequences, which are often made worse by armed conflicts. Mutilation of the genital organs resulting from extreme forms of rape and torture leads to reproductive dysfunction including vaginal destruction, which is a feature that is widely reported in Eastern DRC. Doctors in the DRC have rightly classified vaginal destruction as a crime of combat. Instances of fistula, vaginal bleeding, infections, unwanted pregnancies and sexually transmitted diseases (STDs), including HIV, are some of the consequences of sexual violence. In the $\mathrm{DRC}$, some raped women have had to also go through unsafe abortions.

The social consequences of sexual violence on women have been acknowledged (Bufacchi 2007:112; Duroch et al. 2011:1; Josse 2010:178-182; Le Roux 2014:42; Neuhauser 2015:45; Zihindula \& Maharaj 2015:742). The social consequences have varied negative effects on survivors, ranging from rejection to complete excommunication from the community. How people view survivors of sexual violence is also varied, based on the gender roles and stereotypes associated particularly to sexual behaviours. In some instances, victims become objects of blame for the violence meted on them and held responsible for their misfortunes. There is no doubt that a victim may also blame oneself for the violations, in turn complicating possibilities and chances of healing. Sexual violence against women breaks social conventions, which relate to sexuality by exposing the victims to stigmatisation and discrimination and jeopardising their position in their communities. Sexual violence is humiliating and distressful to the victims. The feelings of shame by the victims and their families (and community) lead to expulsion from family, school, employment, place of worship, legal institutions or from medical facilities. Sexual violence impacts on the marriage of victims. For women in particular, there has been reported abandonment by their husbands once they are raped. In instances where the husband does not abandon the raped wife, he may neglect or even begin to mistreat her. What has been indicated as motivations for abandonment of raped partners include fear of contracting STDs especially $\mathrm{HIV}$, consequences of unwanted pregnancy, the feelings of stigma and loss of face (dishonour) in the community. In the DRC, sexually violated women are likely to be abandoned by their husbands, leading to further marginalisation. Families fear the burden of caring for a person infected by STDs including HIV, particularly when there is an ongoing conflict. During conflict, women who have sexual relations with the enemy combatants are deemed to have defected to the enemy camp and as such treated in the same way as enemy combatants. It is reported that women who have been sexually violated find it hard to go out in public for fear of ridicule. Sexually violated women are dishonoured and rendered unfit for marriage, a further devastation, particularly when marriage is often the only way for women to achieve social and economic status in those communities. These social consequences of sexual violence impoverish and dehumanise women.

The psychological consequences of sexual violence are unbearable. It is revealed (Bufacchi 2007:113; Josse 2010:1; Meger 2010:119-135; Pacéré 2007:4; Zihindula \& Maharaj 2015:742) that the emotional effects that impact the victim are awful both in short and long terms. Emotional responses displayed by victims of sexual violence include but not limited to: fear, anxiety, anguish, depression, shame, guilt, anger, confusion and suicidal tendencies. The fear experienced by some women after sexual violation increases as they are trapped by the fear of repeated assault, including the fear of the social and medical consequences of the violation. The paralysis of fear may keep them away from work, leading to isolation. Some women have been reported to have even moved away from their communities to live in isolated places. Cases of rape on women continue to escalate in Eastern DRC, causing not only physical death but also emotional death, where victims manifest hopelessness. Sexual violence deprives them of their integrity as persons, self-confidence, a sense of personhood and their self-esteem. Their very personhood is compromised and violated. In the DRC, the local construction of masculinity, including the politics and realities of exploitation, continues to shape the people's past, present and future. The Kabila administration continues in its failure to protect the lives of all the people of DRC, as such, there is reliance of the United Nations' peacekeepers. In those regions where the government does not have a strong hold on administration, the locals rely on local militia. This state of affairs allows for conflicts to thrive unchecked and for rape of women to be a constant aspect of the ongoing conflicts. Impunity continues to rule, allowing for the perpetrators to go unpunished. In addition to the occurrences of rape, denial of its very existence is rampant and aids in its proliferation. 
Stated differently, women globally and in Eastern DRC in particular, continue to be vulnerable to sexual violence during times of conflict. The consequences of sexual violence on women impoverish and dehumanise them in more ways than one. For Eastern DRC, the level of sexual violence meted on women has negative physical, emotional and physiological effects, which demand more than mere medical attention, provided by various medical institutions and facilities in Eastern DRC. What approaches can Churches in the region adopt to address the impoverishing and dehumanising effects of not only the conflict in general but also sexual violence meted on women, in particular?

\section{Give churches in Eastern Democratic Republic of Congo a perspective for sustainable livelihoods}

Churches in Eastern DRC continue to offer support to victims of rape. They do so by providing material, financial and medical support. A number of churches assist in the provision of technical training in tailoring and weaving as a means of long-term support. Other churches respond to the challenge of rape by protesting and by taking victims to hospital, including the provision of places and centres of refuge. Members of churches continue to visit rape victims for consolation and solidarity. In addition, churches in the region have express need in the training of men and women in counselling and psycho-social support of traumatic persons; the reinforcement of economic capacity of women who have been raped to help restore their dignity and to aid in their social re-integration; and in the provision of revolving credit opportunities to women in the region (Gilbert 2015:1 of 1; Global Ministries 2014:1 of 1; Nzwili 2009:1 of 1).

An enquiry into what makes women vulnerable during instances of conflicts is critical to any attempt aimed at assisting them overcome their susceptibility to sexual violence and the resultant impoverishing and dehumanising effects of that violence.

A sustainable livelihoods framework can assist in unmasking and correcting women's vulnerability to sexual violence in instances of armed conflict.

Livelihoods are at the core of the sustainable livelihoods framework (De Gruchy 2005:58). Livelihood is what people do each day to not only survive but to also thrive and flourish within the context of their available resources and relationships at their command, including the wider social arrangements that define their place and role in society. A livelihood is about the capacities, assets and activities requisite for a means of living. It is a means of living, of supporting life and meeting individual and community needs. Livelihood is making a living and supporting a family. Sustainable livelihoods (Majale 2002:3; Petersen \& Pedersen 2010:6) is about placing people, especially the vulnerable, at the core of a process and/or a mechanism that enables them to exit impoverishing and dehumanising conditions, into living life as life should be lived. Sustainable livelihoods framework is a mechanism for exiting the poverty of vulnerability by highlighting how to understand, analyse and describe key factors that affect the livelihoods of people. The framework enquires into the assets people draw upon, the strategies they develop to make a living, the context(s) within which a livelihood is developed and the factors that make a livelihood more or less vulnerable to shocks and stress.

International development bodies have used sustainable livelihoods framework to develop sustainable means to combat rural poverty. It assists in understanding the various issues that have a bearing on people's livelihoods. The framework is constructed on the understanding that people require assets to attain and sustain livelihood outcomes, being aware that people in a given community have dissimilar types of assets that can be brought together to obtain a livelihood (Asiimwe 2014:30-32; Korf 2003:131; Petersen \& Pedersen 2010:7).

In this article, the framework not only assists in understanding the different challenges that women in Eastern DRC encounter during conflict, but also how those women may be assisted to meet their everyday needs. The framework assists in understanding how violence against women in contexts of armed conflicts shapes their lives. Their vulnerability frames the external surroundings within which they exist. Their livelihoods and the wider availability of assets are fundamentally affected by trends, shocks and seasonality of the factors and circumstances which they have limited or no control.

It is acknowledged (De Gruchy 2005:60; Duffy 2015:409; Shalhūb-Kīfūrkiyān 2009:42; Turton 2000:15) that the vulnerability contexts of women's assets are shocks that happen unexpectedly, bringing destruction, especially in times of war. When there is war, women suffer from sudden lawlessness and physical damage, including denial of access to their homes and assets. Sexual violence adds to the shock of war. The shocks, which result from armed conflicts, have a greater negative effect on those who have fewer resources, especially women. Women are more vulnerable and experience the brunt of the hardships that come with armed conflicts. Sexual violence in Eastern DRC affects communities where women are greatly involved in agriculture, accounting to over $73 \%$ of those who are economically active in agriculture. Those women produce close to $80 \%$ of the food available in local markets (Gorman 2011:106). It is observed that $80 \%$ of Eastern DRC's population engage in agriculture, with $70 \%$ of them being women (Galloy, Sow \& Hall 2005:25). Owing to ongoing conflicts, women in their numbers are unable to travel to the fiends. Injuries inflicted on women through sexual violence leave them incapacitated and unable to work. The conflict in the DRC has increased the poverty levels tremendously, leaving more than a third of the local population of over 16 million people with critical food deficit. A significant number of the locals in Eastern DRC can afford a meal only once every 2 or 3 days. Their assets, such as land to grow 
food, have become inaccessible, leaving people wrecked by hunger and severe malnutrition (Henriques 2006:133).

It is acknowledged (Asiimwe 2014:33, 37; Mukwege \& Nangini 2009:2) that the attacks inflicted on women working in the fields in Eastern DRC - sexual violence, the cutting of their ears, lips and breasts, and the destruction of their assets - have had a direct bearing on their involvement in agriculture and their inability to sustain their livelihoods. The armed conflict in Eastern DRC has widowed a large number of women and dispossessed them of their access to a means of production, leading to lives lived in abject poverty and a reliance on external aid. Women's abilities to secure the necessities of life is continually curtailed and frustrated.

Communities in Eastern DRC that rely on women for agriculture have been reduced to impoverishing and dehumanising poverty and malnutrition. The alienation of those women from their natural environment, their fundamental base of survival, through the use of sexual violence, has led to reduced access to agricultural production, increasing hunger and malnutrition levels, including increasing the community's dependence on external aid and relief from humanitarian agencies. The reality and the fear of sexual violence, including the general poor safety standards, continue to adversely affect the well-being of not only the women but also entire communities in the region.

The sustainable livelihoods framework is key to exiting impoverishing and dehumanising conditions, such as of sexual violence meted on the women of Eastern DRC. The framework demonstrates how wellness may be achieved, especially when there is the possibility of access to a range of livelihoods, which comprises the physical, natural, social, human and financial capitals. At the core of sustainable livelihoods framework is people and what they have at their disposal to thrive in contexts that make them vulnerable, including the building blocks upon which people undertake production, engage labour markets and participate in reciprocal relationships with others for their very existence (Asiimwe 2014:30). The physical capital comprises basic infrastructures, such as transport, communication, housing, access to water and sanitation, and equipment for production. The social capital is about the social resources requisite to surviving and recovering from shocks and insecurity. These include networking, relationships of trust, membership of groups and access to wider community institutions. It is a complex network of associations, activities and relations that bind people together as a community through norms and psychological capacities such as trust, which is key to collective actions and civility. Violence has negative impact on social capital. War zones are places of social capital deficiency. In Africa, social capital is a means to survival, particularly in the rural areas where it is mediated through cultural rules, norms and practices which guide people's behaviours in their daily social encounters (Asiimwe 2014:35; Deng 2010:231; De Gruchy 2005:60; Farr 2004:6-10). The third capital is the financial capital, which is about financial resources available to people in the community, in terms of livestock, jewellery, cash, savings and credit. These are crucial for the search of any livelihood strategy. The fourth is the human capital, which has two categories, namely knowledge and skills obtained through education, and the physical human body that is in good health, able to work on and transform the other forms of capital, for living (Asiimwe 2014:33-37; Chambers 1995:174; De Gruchy 2005:60; Petersen \& Pedersen 2010:6). The fifth capital is the natural capital (Asiimwe 2014:37; Bebbington 1999:2022; De Gruchy 2005:60; El-Bushra \& Sahl 2005:100), which entails the natural resources accessible to households and communities for pursuit of their livelihoods.

In general, all the five assets in relation to one another are necessary in escaping impoverishment and dehumanisation. They are vehicles for instrumental action (making a living), hermeneutic action (making a living meaningful) and emancipatory action (challenging the structures under which one makes a living). These assets give people the capacity to be and to act. In vulnerability contexts, assets are destroyed by shocks, trends and seasonality of vulnerability context. During armed conflicts, women cannot meet their responsibilities and cannot sustain their well-being. Their vulnerability becomes the depletion of community capital.

When women in Eastern DRC cannot access their land, which is essential to their livelihoods, they suffer loss of income. Their livelihoods are unsustainable because of the shocks that they experience through sexual violence. The fear and reality of sexual violence impoverish them. Women get displaced from their lands. Those who are not displaced are trapped by fear and cannot work on their lands. Women in Eastern DRC should be able to define their goals and act upon them freely without let. They should be free, to do and achieve what they want to. Freedom is central to a life lived in abundance. Their agency is hinged on their capacity to define their own life choices and pursue their own goals. Within the sustainable livelihoods framework, as De Gruchy (2005:65) observes, is the demand for transformation of structures and processes within the livelihoods context. The structures and processes include those institutions, organisations, policies and legislations, which shape livelihoods. It is an action designed to achieve particular goals and targets. Structures make processes to function in particular ways, such that the absence of appropriate structures can be a major limitation to responses to situations, which impoverish and dehumanise. Structures and processes do not always benefit vulnerable people, resulting in failure to recognise legitimate interests, particularly of the vulnerable.

The sustainable livelihoods framework is mainly about outcomes (De Gruchy 2003:31; De Gruchy 2005:63; Oikos Study Group 2006:16). Sustainability is about thinking of livelihoods through promotion of responsiveness. It is a focus on what actually happen. Its achievement orientation provides the basis for action. The framework seeks positive outcomes, such as increased well-being of the vulnerable, 
more income, reduced vulnerability, improved food security and more sustainable use of the natural resource base. The aim is to achieve positive outcomes; even though in reality, undesirable outcomes sometimes occur. It is acknowledged that not all people may value material goods, but people value their well-being. In the case of women, well-being is affected byvariousfactors, whichmayincludeself-esteem, sense of control and the physical security of household numbers. In order to assist women who for this case are victims of sexual violence in Eastern DRC, their livelihood outcomes can be sustained through a mediating role, between them and (the governing) authorities, by churches in the region.

Sustainable livelihoods framework helps in placing people at the heart of what affects them in the community and how they can create livelihoods by themselves. Churches can stand as mediators and advocate for women's need to exit impoverishing and dehumanising situations, especially those caused by sexual violence within contexts of armed conflicts.

\section{Churches as advocates for women affected by sexual violence in contexts of armed conflicts in Eastern Democratic Republic of Congo}

There are a number of ways that churches can mediate on behalf of women dealing with the reality of sexual violence, within Eastern DRC. There is a need for churches to embrace advocacy as a vehicle for change.

Various verses in the Bible, such as Proverbs 31:8-9 (Speak up for those who cannot speak for themselves, for the rights of all who are destitute. Speak up and judge fairly; defend the rights of the poor and needy [NIV]) and Micah 6:8 (He has shown you, O mortal, what is good. And what does the Lord require of you? To act justly and to love mercy and to walk humbly with your God $[N I V])$, for example, call upon churches to express their faith in creative ways on behalf of the powerless, the destitute and those who have been robbed of their voices. The kinds of injustice that rob others of their voices, while amplifying it for others, continue to prevail in many communities around the world (Kooyman 2010:1 of 1) and in Eastern DRC in particular. The advocacy role by churches is rooted in the hope and promise that believers in Christ have for a better future. Churches play advocacy roles in the confidence that God is working his purposes out; as Christians look forward to justice, not revenge (Romans 12:19 Do not take revenge, my dear friends, but leave room for God's wrath, for it is written: It is mine to avenge; I will repay, says the Lord). Advocacy is part of the church's calling to be salt and light in the world (Mathew 5:13-16 Your are the salt of the earth ... You are the light of the world. ... let your light shine before others, that they may see your good deeds and glorify your Father in heaven [NIV]). Churches have a mission of working with God to bring about God's Kingdom, which is characterised by the good news of Jesus Christ and includes social justice; reconciliation with God, humanity and creation; peace; and God's material blessings (Gordon \& Evans 2002:2, 16).

Numerous agencies and organisations, such as the non-profit and non-governmental organisations (NPOs \& NGOs), can and may play advocacy roles in communities. However, the kind of advocacy that churches effect is strategic and unique in motivation and nature (Chew 2015:198; Raistrick n.d.:1-3). Churches have the ability to exert real power and influence on local issues and local power brokers on the following accounts: Firstly, churches as part of communities are able to see and experience local injustice first-hand, as such can be in a position to take action. Secondly, churches are arguably influential, sustainable and indigenous. As such they can empower citizens at the grassroots. Thirdly, churches are ideally placed to gather first-hand accounts and information of what happens at local levels. Such accounts can inform and strengthen the church's advocacy role. Fourthly, churches are uniquely placed to share useful information with their members and communities that can inform and strengthen their advocacy work. Fifthly, churches are a force for reconciliation in communities. Churches bring a strong value base and theology that is sympathetic to reconciliation. It must be noted, however, that churches have in some instances been guilty of serious abuses. Sixthly, the value of prayer in advocacy cannot be diminished. Prayer plays a significant role in the shaping and influencing of the attitudes (hearts and minds). Prayer plays a critical role in the church's advocacy. It would be amiss if it were not acknowledged that churches do already play advocacy roles, even if they do not use the term. For churches, standing up for the oppressed and for the vulnerable is a natural thing to do.

It is observed (Casey 2011:7-13; Gordon 2010:2) that advocacy is about pleading, defending and recommending. It is an action directed at changing positions and programmes of policies. It is about calling to another's aid or speaking out on behalf of someone. It is about speaking on behalf of the oppressed and the marginalised, to bring change. Oppression reduces the potential of the oppressed to be fully human. Advocacy is about speaking on behalf of those treated in dehumanising ways. Advocacy is the attempt to influence public policy and practice including other decisions of the elite. It is about active espousal of a point of view and/or a course of action. It is seeking with, and on behalf of the vulnerable, to address underlying causes of vulnerability, bringing justice and support, through influencing the policies and practices of the powerful. For the churches in Eastern DRC, advocacy has to be about speaking on behalf of those women who have been sexually violated or face the danger of sexual violation within the context of the ongoing armed conflict.

Policy advocacy, a process of negotiating and mediating a dialogue through which influential networks, opinion leaders and decision-makers take over ideas, proposals and act upon them to assist the powerless, the stigmatised and the oppressed, ultimately leading to improvement of their 
living conditions and well-being (Ezell 2000:23; Young \& Quinn 2012:26), is critical to the role of churches in Eastern DRC.

Available demographics (Adogla 2010:17; Le Roux 2014:101-102; Whetho \& Uzodike 2008:73) show that DRC has over $79 \%$ of her population claiming to be Christians. The Roman Catholic Church is the largest with $50 \%$ of the population, the Protestant denominations carry 20\%, while Kimbanguists, who are categorised as Christians, represent 9\%. Other religions are the Bahai, 0.4\%; Islam, 9\% and African faiths, $7 \%$. In the light of her numbers, Churches in the DRC can be an influential part of the society. The churches, however, have not done enough to respond to human rights abuses. There are accusations to the effect that some churches have actually been collaborating with regimes responsible for atrocities that have bedevilled the DRC. It must be noted, however, that the Catholic Church has considerable influence in various spheres and has in the past contributed to the democratisation processes in the 1990s. The unending armed conflicts appear to have rendered some churches unable to offer moral guidance. Various churches have struggled to play any significant roles in the provision of social services, such as health, education and communication for her members and the wider society. Although some church denominations appear to have lost their ability to challenge the government, the Catholic Church seemingly appear to still have some moral and intellectual authority, and is seen as capable of offering spiritual support including being a voice to the voiceless. By and large, churches in recent years, have collaborated with NGOs and civil society groups in the provision of basic services such as medical care, counselling, education and training for those who have suffered sexual violence. With specific regard to Eastern DRC, findings show that churches in the region have offered little to help women affected by sexual violence. Worse, in many - if not most - cases, churches in the region have desisted from any involvement in any efforts to address issues of sexual violence. Reports show that churches seem reluctant and in some instances, opposed, to mobilisations around women's issues.

Churches in Eastern DRC have to be advocates for women facing sexual violence, motivated by the compassion of Christ towards those in need, the suffering, the oppressed and the poor. Doing so, is consistent with the demands of the mission of the church to bring good news and help extend God's Kingdom on earth, through caring for those in need, defending the cause of weak, speaking against injustice and working for change. Advocacy is part of the overall mission of the church. Because churches in Eastern DRC live within the realities of armed conflict and the resultant sexual violence against women; they are also included in the marginalised. As such, the marginalised can be agents of their own change. The marginalised have a role in their redemption. Churches, therefore, have the responsibility to pray for God's intervention, model an alternative way of life, be active in social action, seek justice for the vulnerable by engaging those in power, actively working for peace and reconciliation, speaking prophetically against injustice, and confronting any unseen powers which impoverish and dehumanise the vulnerable (Dalrymple \& Boylan 2013:2; Gordon 2010:37; Teff \& Campisi 2010:16).

Theorists of yester years (Moltmann 1984:48; Thorogood 1991:50-52) have legitimised the role of churches in advocacy, noting that the prophetic ministry of advocacy is within the realm of what can be done best by churches, on account of features that churches have. Churches are by and large endowed with self-criticality and neutrality, which are partly necessary to a promotion and realisation of human rights cultures. The struggle to attain a just society is a religious matter. The cooperation of churches with other agencies that fight for justice goes a long way into attaining justice and dignity for the vulnerable, the oppressed and the poor. It is sad when churches become oblivious to the pain and suffering of the vulnerable, as in Eastern DRC, where churches are yet to demonstrate a measurable concern against the injustice of sexual violence against women.

\section{A problem, a framework and a purpose: The churches' advocacy for sustainable livelihoods against sexual violence in Eastern Democratic Republic of Congo}

The advocacy role by churches in the region has to be about building and transformation of structures and processes for better outcomes. The sustainable livelihoods framework is a very helpful tool for an advocacy role by churches, especially in Eastern DRC. The framework contributes to an understanding of the livelihoods of the vulnerable. As churches respond using the framework, their focus is trained towards the key factors that affect livelihoods and relationships between those factors. The advocacy role by churches in the region, done from a sustainable livelihoods viewpoint, gives prominence to the reality of livelihoods as shaped by a multitude of different forces and factors that constantly shift. It is a people's centred approach, which highlights the need for an agitation for the transformation of structures and processes; and the vulnerability context as well. As stated earlier, the vulnerability context, particularly that of the women in Eastern DRC, is mainly outside of their control. There is a need, therefore, for activities at the levels of transformation of structures and processes, including changes in policies, which have allowed for continued armed conflict in the region.

\section{Advocacy for the nurturing of human capital}

Churches in Eastern DRC can effectively play their advocacy role by creating spaces for the nurturing of human capital. There has to be a realisation among church leaders and church members in the region that skills knowledge and good health is key to pursuits for livelihoods. 
Advocacy for a nurturing of human capital and agitation for a nurturing of knowledge and labour, including the building of capacities to command labour, are of intrinsic value. This is important for achieving positive livelihood outcomes.

Among the vulnerable, especially the women of Eastern DRC, churches have to allow their church spaces to be used as venues for training sessions, as schools and as places where medical services may be dispensed. Any policies and/or structures which stand in opposition to such efforts will have to be resisted and changes proposed. Social norms that prevent women and other vulnerable individuals from accessing these spaces and facilities, have to be identified and corrections advocated for.

There is a need for churches to partner with those who have led previously in the provision of social services in general and provision of education and health services in particular, such as the Catholic Church.

There is a need for churches to explore ways of generating income through group fundraising, to assist in the provision of financial reserves, which may be borrowed and paid back by members, in their attempts to nurture and enhance their livelihoods.

Churches have to accept that their church properties will have to be spaced and have venues for participatory processes of knowledge generation and capacity building with a view to complement existing local knowledge and sources of well-being.

\section{Advocacy for the nurturing of social capital}

The advocacy role by churches in Eastern DRC will have to include an agitation for nurturing of social capital. Social resources upon which all the inhabitants of the region draw in pursuit of their livelihoods: their resources and connectedness, their membership in groups and relationships of trust, including reciprocity and exchange, have to be nurtured.

Churches have to agitate for a nurturing of trust among communities, groups and individuals in the region. Mutual trust among the peoples of the region, will lower the cost of working together, which in turn will positively enhance economic relations and raising the people's potential to increase their income. An agitation for a nurturing of mutual trust has a direct positive impact in the utilisation of available common resources and shared infrastructure. Building of mutual trust allows for the possibility of innovations and development of knowledge, including a mutual sharing of such knowledge.

There is no room for doubt that women in Eastern DRC are largely excluded from memberships in strong-armed militia and government groups. In addition, the hierarchical nature of gender stereotypes in the region limit women's mobility and prevents them from escaping vulnerability.

Social capital (network and connectedness; membership of groups; and relationships of trust, reciprocity and exchange) can be nurtured in Eastern DRC through efforts by churches to strengthen local institutions that serve the interests of the vulnerable. There is a need for churches in the region to agitate for an injection of resources into the region, to be used for capacity building, leadership training and the creation of an open, democratic environment, where everyone, especially the vulnerable, can thrive.

Churches have to agitate for the empowerment of individual women and women groups, by allowing church spaces to be venues and spaces of participatory community participation. Participatory engagements among women and the rest of the community peoples in the region allow for a nurturing of community knowledge(s), which can enable individuals and groups to live lives that have the possibility of creating choices and freedoms.

\section{Advocacy for the nurturing of natural capital}

As discussed earlier, the armed conflict in Eastern DRC has its roots partly in the fight for control, access and extraction of the natural resources in the region. An agitation for the nurturing of natural capital will have to entail a new way of thinking about those natural resources. It cannot be overstated, that there is a direct link between those natural resources and a derivation of resource flows and services useful for the livelihoods of the peoples of the region.

The factors, which have contributed significantly to impoverishment and dehumanisation of the women of Eastern DRC, have revolved around the relationship between the natural capital and the processes and structures (i.e. armed capital), that inhibit access to that capital. For the peoples of the region, access to natural capital (land, farms, forests, minerals) is necessary, as they derive part or all of their livelihoods from that access. The agitation by churches for the protection and fair access to natural capital is significant to achieving livelihoods by all the peoples of the region. As such, churches will have to draw the attention of communities to sustainable ways of protecting the environment. Although it may be argued that the level of environmental awareness might not be a priority for some, churches have to strive to demonstrate to communities the link between natural resources and their dependence of them, for their health and well-being. Churches have to teach communities in the region about the complex functioning of ecosystems, which are often ignored or undervalued until the adverse effects of disturbing them become apparent.

Churches in the region will have to advocate for fair processes and structures responsible for land allocations, including fair rules that govern extraction of minerals. There has to be a 
framework on how natural capital should be used to benefit every member of the communities in the region. Churches will have to agitate for fair access to natural resources and the provision of incentives necessary for improved resource management. Such efforts must include the creation of markets that allow for fair exchange of commodities. Churches will have to advocate for the provision of support to enable the vulnerable to access and use those resources.

\section{Advocacy for the nurturing of physical capital}

The sustainable livelihoods framework, assists churches in Eastern DRC to advocate for nurturing of basic infrastructure and producer goods requisite to livelihoods. There is a need for an agitation for structural changes that would allow for a conducive physical environment upon which communities can meet their basic needs and be more productive. The communities in the region need tools and equipment for productive functioning.

Because of protracted armed conflict, churches have to advocate for a nurturing of affordable transport, secure shelters, access to adequate safe water and sanitation, access to affordable electricity and access to information.

The framework enables churches to make a case before authorities in the DRC, for access to services (i.e. water and electricity) as such access has a direct impact on the health of individuals and communities. Women in the region should not be spending long periods in non-productive activities such as water and wood (fuel) collection.

\section{Advocacy for the nurturing of financial capital}

Financial resources are necessary to achieving livelihoods. Availability of adequate cash (or equivalent) that enables communities and individuals to generate life options and strategies has to be nurtured in Eastern DRC. Churches in the region have to allow for the use of intra-, inter- and transnetworks and relationships as spaces for the generation of cash and places for deposits of liquid assets (i.e. jewellery), including the provision of credit for church members and the vulnerable in communities. Churches will have to use their networks and relationships as collateral on behalf of the vulnerable that do not qualify for credit.

By partnering with government agencies, churches in the region will have to agitate for versatility of individual and community assets. Assets have to be easily convertible, as such, churches have to identify and oppose structures and processes that make versatility of assets impossible. By using collective influence, churches will have to advocate for reforms that respect the people's rights and freedoms to active participation in organisations that formulate policies and legislations and govern access to resources.

Although it is not the direct responsibility of churches to hand out money to the vulnerable in communities, churches may utilise indirect means to enable the vulnerable to access financial capital. Such means may include: helping in the development of effective, tailored financial organisations for the vulnerable; increasing access to financial services by opposing barriers associated with lack of collateral among the vulnerable; and by working for the reform of the environment in which financial services operate, in order for the provision of better safety nets for the vulnerable.

\section{Conclusion}

By adopting a sustainable livelihoods framework, churches in Eastern DRC will respond, meaningfully and in a composite manner, to sexual violence meted on women in the region. The kind of advocacy by churches advanced through the lenses provided by the framework allows churches to agitate for increased overall social sustainability of women's livelihoods, thus enabling responses to their vulnerability. The approach enables churches to advocate for improved food security, which is a core dimension of women's vulnerability. By agitating for fair, equitable and sustainable use of natural resources, the need for armed conflict in the region may be reduced. As such, a peaceful environment will allow for activities that bring (more) income, not only among women but also for communities in the region.

\section{Acknowledgements Competing interests}

The author declares that he has no financial or personal relationships that may have inappropriately influenced him in writing this article.

\section{References}

Adogla, E.C., 2010, 'Religiously remapped 3.0: Mapping religious trends in Africa' viewed 01 April 2016, from http://www.religiously.remapped.info

Arbuckle, G.A., 2004, Violence, society, and the Church: A cultural approach, Liturgical Press, Collegeville, PA.

Asiimwe, S., 2014, 'Female livelihoods in war-affected societies: Cases from Kitgum District of Northern Uganda', Master's thesis in peace and conflict transformation Faculty of Humanities, Social Science and Education, The Artic University of Norway.

Bebbington, A., 1999, 'Capitals and capabilities: A framework for analyzing peasant viability, rural livelihoods and poverty', World Development 27(12), 2021-2044. https://doi.org/10.1016/S0305-750X(99)00104-7

Bufacchi, V., 2007, Violence and social justice, Palgrave Macmillan, New York.

Casey, J., 2011, 'Understanding advocacy: A primer on the policy making role of nonprofit organizations', viewed 31 March 2016, from https://www.baruch.cuny. edu/spa/centers-and-institutes/center-for-nonprofit-strategy-and-management/ documents/Casey_UnderstandingAdvocacyaPrimeronthe Policy Making documents/Casey_Understanding
RoleofNonoprofitOrganizations.pdf

Chambers, R., 1995, 'Poverty and livelihoods: Whose reality counts?', Environment and Urbanization 7(1), 173-204. https://doi.org/10.1177/095624789500700106

Chew, P.G.L., 2015, 'Women of faith and advocacy', in K. Soin \& M. Thomas (eds.), Our lives to live: Putting a woman's face to change in Singapore, pp. 191-198, World Scientific, London.

Dalrymple, J. \& Boylan, J., 2013, Effective advocacy in social work, Sage, London.

De Gruchy, S., 2003, 'Of agency, assets and appreciation: Seeking some commonalities between theology and development', Journal of theology for Southern Africa 16(117), 20-39.

De Gruchy, S., 2005, 'A Christian engagement with the sustainable livelihoods framework', Missionalia 33(1), 56-72.

Deng, L.B., 2010, 'Social capital and civil war: The Dinka communities in Sudan's civil war', African Affairs 109(435), 231-250. https://doi.org/10.1093/afraf/adq001

Dossa, N.I., Zunzunegui, M.V., Hatem, M. \& Fraser, W., 2014, 'Fistula and other adverse reproductive health outcomes among women victims of conflict-related sexual violence: A population-based cross-sectional study', Birth 41(1), 5-13. https://doi. org/10.1111/birt.12085 
Duffy, L., 2015, 'Achieving a sustainable livelihood after leaving intimate partner violence: Challenges and opportunities', Journal Of Family Violence 30(4), vio3-417. https://doi.org/10.1007/s10896-015-9686-x

Duroch, F., McRae, M. \& Grais, R.F., 2011, 'Description and consequences of sexual violence in Ituri province, Democratic Republic of Congo', BMC International Health and Human Rights 11(1), 1. https://doi.org/10.1186/1472-698X-11-5

El-Bushra, J. \& Sahl, I.M., 2005, Cycles of violence: Gender relations and armed conflict, Acord, Nairobi.

Ezell, M., 2000, Advocacy in the human services, Cengage Learning, Belmont, CA.

Farr, J., 2004, 'Social capital a conceptual history', Political Theory 32(1), 6-33. https:// doi.org/10.1177/0090591703254978

Fowler, C., 2011, Rape in Congo: How culture, warfare, and American politics impact women in the DRC, viewed 05 October 2016, from http://scholar.colorado.edu/ $\mathrm{cgi} /$ viewcontent.cgi? ?article $=1863 \&$ context=honr_theses

Freedman, J., 2011, 'Explaining sexual violence and gender inequalities in the DRC', Peace Review: A Journal of Social Justice 23(2), 170-175. https://doi.org/10.1080 /10402659.2011.571601

Galloy, M.R., Sow, N. \& Hall, C. (eds.), 2005, Women's bodies as a battleground: Sexual violence against women and girls during the war in the Democratic Republic of Congo, South Kivu (1996-2003), viewed 30 March 2016, from http://www. international-alert.org/sites/default/files/publications/women\%27s-bodies-as-aenglish.pdf

Gilbert, K.L., 2015, 'Congo churches help rape victims', The people of The United Methodist Church, viewed 07 October 2016, from http://www.umc.org/newsand-media/rape-victims-find-help-at-united-methodist-churches

Global Ministries, 2014, 'Survivors of violent rape in the Congo', viewed 07 Octobe 2016, from http://www.globalministries.org/africa/projects/survivors-of-violentrape-in.html

Gordon, G., 2010, Understanding advocacy, Tearfund, Teddington.

Gordon, G. \& Evans, B., 2002, 'The mission of the church and the role of advocacy', viewed 04 October 2016, from http://place.asburyseminary.edu/cgi/viewcontent cgi?article $=1004 \&$ context=engaginggovernmentpapers

Gorman, M., 2011, 'Sexual violence in the Democratic Republic of Congo', Undergraduate Transitional Justice Review 1(2), 99-138.

Henriques, Z., 2006, 'The invisible conflicts in the Democratic Republic of the Congo (DRC)', Journal of Ethnicity in Criminal Justice 4(1/2), 129-143. https://doi. org/10.1300/J222v04n01 06

Josse, E., 2010, 'They came with two guns': The consequences of sexual violence for the mental health of women in armed conflicts', International Review of the Red Cross 92(877), 177-195. https://doi.org/10.1017/S1816383110000251

Kelly, L., 2000, 'Wars against women: Sexual violence, sexual politics and the militarised state', in S. Jacobs, R. Jacobson \& J. Marchbank (eds.), States of conflict: Gender, violence and resistance, pp. 45-65, Zed Books, London.

Kirk-Duggan, C.A., 2006, Violence and theology, Abingdon Press, Nashville, TN.

Kooyman, K., 2010, Why Christians should be involved in advocacy, viewed 04 Octobe 2016, from http://network.crcna.org/global-mission/why-christians-should-beinvolved-advocacy

Korf, B., 2003, 'Livelihoods at risk: Coping strategies of war-affected communities in Sri Lanka', Journal of Agriculture and Rural Development in the Tropics and Subtropics 104(2), 129-141.

Leatherman, J., 2011, Sexual violence and armed conflict, Polity Press, Cambridge.

Le Roux, E., 2014, The role of African Christian churches in dealing with sexual violence against women: The case of the Democratic Republic of Congo, Rwanda and Liberia, Doctoral dissertation, Faculty of Arts and Social Sciences, Stellenbosch University.

Majale, M., 2002, Regulatory guidelines for Urban upgrading: Towards effecting propoor change, ITDG, Warwickshire.

Meger, S., 2010, 'Rape of the Congo: Understanding sexual violence in the conflict in the Democratic Republic of Congo', Journal of Contemporary African Studies 28(2), 119-135. https://doi.org/10.1080/02589001003736728

Melhado, L., 2010, 'Rates of sexual violence are high in Democratic Republic of the Congo', International Perspectives on Sexual and Reproductive Health 36(4), 210-210.
Moltmann, J., 1984, On human dignity: Political theology and ethics, Fortress Press, Philadelphia, PA.

Moore, P., 2016, More UN peacekeepers accused of sex crimes, Mail \& Guardian, viewed 05 October 2016, from http://mg.co.za/article/2016-04-06-unpeacekeepers-accused-of-sex-crimes

Mukwege, D.M. \& Nangini, C., 2009, 'Rape with extreme violence: The new pathology in South Kivu, Democratic Republic of Congo', PLoS Med 6(12), 1-5. https://doi. org/10.1371/journal.pmed.1000204

Nest, M.W., Grignon, F. \& Kisangani, E.F., 2006, The Democratic Republic of Congo: Economic dimensions of war and peace, Lynne Rienner Publishers, Boulder, CO.

Neuhauser, J., 2015, 'Constrained desire for mobility and the rejection of the victim subject: The negotiation of trafficking discourses in Brazilian sex workers' narratives', Transnational Social Review 5(1), 39-54. https://doi.org/10.1080/219 31674.2015 .1022378

Nzwili, F., 2009, 'Churches support victims of rape in Democratic Republic of Congo', World Council of Churches, viewed 07 October 2016, from https://www. oikoumene.org/en/press-centre/news/churches-support-victims-of-rape-in-theoikoumene.org/en/press-centre/

Oikos Study Group, 2006, The Oikos journey: A theological reflection on the economic crisis in South Africa, viewed 31 March 2016, from http://www.diakonia.org.za/ wp-content/uploads/bsk-pdf-manager/39_The_Oikos_Journey_3.pdf

Pacéré, T., 2007, 'Progress report submitted by the independent expert on the situation of human rights in the Democratic Republic of the Congo', in Promotion and protection of human rights: Human rights situations and reports of special rapporteurs and representatives, United Nations General Assembly, New York.

Petersen, E.K. \& Pedersen, M.L., 2010, The sustainable livelihoods approach, Aarhus, Institute of Biology, University of Aarhus, viewed 29 March 2016, from http:// ps.au.dk/fileadmin/Statskundskab/Dokumenter/subsites/Uland/ ps.au.dk/fileadmin/Statskundskab/Do
TheSustainableLivelyhoodsApproach_Psych.pdf

Raistrick, T., n.d., 'The strategic role of the church in advocacy', viewed 05 October 2016, from http://tilz.tearfund.org/en/themes/church/church_and_advocacy/ the_strategic_role_of_the_church_in_advocacy

Reyntjens, F., 2009, The great African war: Congo and regional geopolitics, 1996-2006, Cambridge University Press, Cambridge.

Shalhūb-Kīfūrkiyān, N., 2009, Militarization and violence against women in conflict zones in the Middle East: A Palestinian case-study, Cambridge University Press, New York.

Spangaro, J., McNamara, L., Blyth, J., Myers, B. \& Boxwell, R., 2015, 'Use of intimate photography in sexual assault prosecution: Who is being deterred?', Psychiatry Psychology and Law 22(5), 682-687. https://doi.org/10.1080/13218719.2014.96 5294

Teff, M. \& Campisi, C., 2010, Preventing sexual violence, Forced Migration Review (36), $16-17$.

Thorogood, B., 1991, One wind, many flames: Church unity and the diversity of the churches, WCC Publications, Geneva.

Turner, T., 2013, Congo, Wiley, Cambridge.

Turton, C., 2000, The sustainable livelihoods approach and programme development in Cambodia, Overseas Development Institute, London.

Watts, C. \& Zimmerman, C., 2002, 'Violence against women: Global scope and magnitude', The Lancet 359(9313), 1232-1237. https://doi.org/10.1016/S01406736(02)08221-1

Whetho, A. \& Uzodike, U.O., 2008, 'Religious networks in post-conflict Democratic Republic of the Congo: A prognosis', African Journal on Conflict Resolution 8(3), 57-84.

Wood, E.J., 2006, 'Sexual violence during the war: Towards an understanding of variation', in L. Sjoberg \& S. Vila (eds.), Gender, war, and militarism: Feminist perspectives, pp. 124-138.

Young, E. \& Quinn, L., 2012, Making research evidence matter: A guide to policy advocacy in transition countries, Open Society Foundations, Budapest.

Zihindula, G. \& Maharaj, P., 2015, 'Risk of sexual violence: Perspectives and experiences of women in a hospital in the Democratic Republic of Congo', Journal of Community Health 40(4), 736-743. https://doi.org/10.1007/s10900-015-9992-5 